\title{
Antifosfolipid antikor ilişkili adrenal hemorajiye bağlı gelişen akut adrenal yetmezlik
}

Antiphospholipid antibody associated adrenal hemorrhage causing acute adrenal insufficiency

\author{
Banu Şarer Yürekli ${ }^{1}$ Hatice Özışık ${ }^{1} \quad$ Nilüfer Özdemir Kutbay ${ }^{1} \quad$ Gökçen Ünal Kocabaş ${ }^{2}$ \\ Mehmet Erdoğan ${ }^{1} \quad$ Şevki Çetinkalp ${ }^{1} \quad$ Gökhan Özgen $^{1} \quad{\text { Kenan } \mathrm{Aksu}^{3}}^{3} \quad$ Füsun Saygıllı ${ }^{1}$ \\ ${ }^{1}$ Ege Üniversitesi Tıp Fakültesi, İç Hastalıkları Anabilim Dalı, Endokrinoloji Bilim Dalı, İzmir, Türkiye \\ ${ }^{2}$ Bozyaka Eğitim ve Araştırma Hastanesi, Endokrinoloji Kliniği, İzmir, Türkiye \\ ${ }^{3}$ Ege Üniversitesi Tıp Fakültesi, İç Hastalıkları Anabilim Dalı, Romatoloji Bilim Dalı, İzmir, Türkiye
}

\section{Öz}

Antifosfolipid antikor (AFA) varlığında arteriyel ya da venöz tromboz görülebilir. Antifosfolipid sendromunda görülen tromboza yönelik değişik patogenetik mekanizmalar ileri sürülmüştür. Burada 62 yaşında AFA'nın eşlik ettiği adrenal hemorajiye bağlı adrenal yetmezlik vakası sunulmaktadır. AFA sendromlarında daha sık görülen pulmoner emboli ve derin ven trombozunun yanı sıra adrenal venlerde de trombotik sürecin olabileceği akılda tutulmalıdır.

Anahtar Sözcükler: Antifosfolipid antikor, adrenal yetmezlik, adrenal hemoraji.

\begin{abstract}
Arterial or venous thrombosis can be seen in the presence of antiphospholipid antibody. Various pathogenetic mechanisms are put forward in case of antiphospholipid syndrome. Herein a case of 62-year-old male patient who developed adrenal hemorrhage leading to adrenal insufficiency was presented. It should be kept in mind that thrombotic process of antiphospholipid syndrome could be seen in adrenal veins in addition to pulmonary and deep vein thrombosis.
\end{abstract}

Keywords: Antiphospholipid antibody, adrenal insufficiency, adrenal hemorrhage.

\section{Giriş}

Antifosfolipid antikorlar (AFA), protein-fosfolipid komplekslere karşı gelişen heterojen otoantikorlardandır. AFA varlığında görülen arteriyel ya da venöz tromboza yönelik değişik patogenetik mekanizmalar ileri sürülmüştür. AFA, protein $C$ ve protein $S$ inhibitör sistemini bozabilmektedir. Endotel hücreleri tarafından prostosiklin sentezini azaltmaktadırlar. Doku faktör aktivitesini arttırabilmektedirler (1). Primer adrenal yetmezlik 100.000 'de 0.8 oranında görülmektedir. Otoimmün adrenalit tüm hipoadrenalizm vakalarının \%70'ini oluşturmaktadır. AFA ve akut adrenal yetmezlik arasındaki ilişki literatürde belirtilmiştir (1). Sürrenaldeki AFA'ya bağlı tromboz sürrenalde hemorajiye yol açabilir. $\mathrm{Bu}$ yazıda, AFA ilişkili adrenal hemorajisi olan akut adrenal yetmezlik vakasını ve yetmezliği yaratan patogenetik mekanizmaları irdelemek istedik.

Yazışma Adresi: Banu Şarer Yürekli

Ege Üniversitesi Tıp Fakültesi, İç Hastalıkları Anabilim Dalı, Endokrinoloji Bilim Dalı, İzmir, Türkiye

Makalenin Geliş Tarihi: 09.12.2015
Kabul Tarihi: 16.02.2016

\section{Olgu Sunumu}

Halsizlik, bilinç bulanıklığı ve tansiyon düşüklüğü ile 2009'da Nefroloji Bölümü'ne başvuran 62 yaşında erkek hastaya çekilen kraniyal MR'da subakut infarkt tespit edildi. 2004'ten bu yana kronik böbrek hastalığı ile takip edilmekteydi. Geçmiş medikal öyküsünde hipertansiyon ve tekrarlayan venöz tromboemboli vardı. Ancak hastanın trombofili paneli bakılmadığı için trombofili ekarte edilemedi. Kreatinin değerlerindeki progresif artış nedeniyle yapılan renal biyopside tubulo interstisyel nefrit tespit edildi. Tansiyon düşüklüğü, Na:121meq/L (136-145 meq/L) ve K:6.2 meq/L (3.5-5 meq/L) olan hastada akut adrenal yetmezlikten şüphelenilerek bakılan kortizol değeri $4 \mu \mathrm{g} / \mathrm{dL}(5-25 \mu \mathrm{g} / \mathrm{dL})$, ACTH değeri $341 \mathrm{pg} / \mathrm{mL}(10-46 \mathrm{pg} / \mathrm{mL})$ olarak saptandı. Akut adrenal yetmezlik tanısı nedeniyle çekilen abdomen MR'da her iki sürrenal bezde sinyal karakteristikleri ve belirgin kontrast tutmaması nedeniyle hematom düşünüldü (Şekil-1a). Tekrarlayan venöz tromboemboli, kreatinin progresyonu göz önüne alınarak yapılan laboratuvar tetkiklerinde aPTT 36.4 sn (23.2-34.7), C3 $88 \mathrm{mg} / \mathrm{dL}(90-180 \mathrm{mg} / \mathrm{dL})$, ANA:1/160 homojen pozitif granüler, anti-dsDNA:28 IU/mL $(<20 \quad \mathrm{IU} / \mathrm{mL})$, 
antikardiyolipin IgG (ELISA):282 GPL U/mL $(<10 \mathrm{GPL}$ $\mathrm{U} / \mathrm{mL}$ ), antikardiyolipin IgM (ELISA):12 MPL U/mL $(<7$ MPL $U / \mathrm{mL}$ ) tespit edildi. İlk ölçümden 12 hafta sonra bakılan antikardiyolipin antikorları da yüksek saptandı. Tam idrar tetkiki normal geldi. Hasta ANA pozitifliği, antidsDNA pozitifliği, kompleman düzeyi düşüklüğü olması ve klinik bulgu olarak skar bırakmayan alopesisi olması nedeniyle sistemik lupus eritomatozis (SLE) tanısı aldı. Tekrarlayan tromboemboli öyküsü ve AFA pozitifliği olan hastada SLE'e sekonder AFA sendromu düşünüldü. SLE için hidroksiklorokin $200 \mathrm{mg}$ 1x1 başlandı. Adrenal hemorajiye bağlı adrenal yetmezlik düşünülen hastaya stres dozunda steroid tedavisi $(80 \mathrm{mg} / \mathrm{gün}$ metilprednizolon) başlandı. Derin ven trombozu nedeni ile warfarin kullanmakta olan hastanın INR değeri hastaneye başvurusunda 1.6 olması nedeniyle adrenal hemorajinin ilaca bağlı olmadığı düşünüldü. Tekrarlayan trombozu olması nedeniyle warfarine devam edilen hastada INR hedefi 2-3'tü. Hastamızdaki adrenal hemoraji AFA ilişkili infarktın yarattığı hemorajiye bağlandı. Hastanın takipte 1.5 ay sonra çekilen MR'larında hemorajik görünümde gerileme oldu (Şekil1b). Hastanın yapılan son kontrollerinde çekilen sürrenal MR görüntüleri tamamen normale dönmesine rağmen sürrenal yetmezliği kliniği devam etmekte ve hasta halen $30 \mathrm{mg} / g u ̈ n$ hidrokortizon ile izlenmeye devam etmektedir.

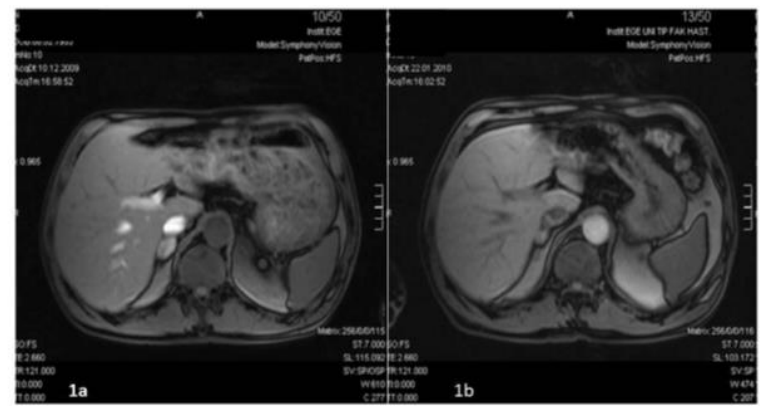

Şekil-1.a. MR'da adrenal hemoraji görünümü. b. Adrenal hemorajide gerileme

Hastadan tıbbi verilerinin yayınlanabileceğine ilişkin yazılı onam belgesi alındı.

\section{Tartışma}

AFA sendromu trombotik bir süreç olmasına rağmen, antifosfolipid sendromunun adrenal hemorajiye nasıl yol açtığı henüz anlaşılamamıştır. İki olası mekanizmadan bahsedilmektedir. Birincisi, adrenal bezin kendine özgü vaskülarizasyonunun olmasıdır. Adrenal bez zengin arteriyel kanlanmaya sahiptir ancak sınırlı venöz drenaja sahiptir. Kan akımı, küçük arterleri oluşturmak için dallanan 3 ana arterden sağlanır. Bu küçük arterler bezin yüzeyine penetre olur ve zona glomerulosa ve zona reticularise kadar uzanır. Adrenal korteksin en içteki bölgesi olan zona reticulariste, kapiller pleksus medüller sinusoide ve oradan büyük santral vene dökülür.
Arterden kapiller pleksusa geçiş ani bir şekilde olmakta, bu durum kanın göllenmesine ve stazına neden olmaktadır (1-3). Sürrenal bez kısıtlı venöz drenajı, venöz tromboz olması halinde bez içi hidrostatik basıncı artırarak kanamaya neden olabilir. İkinci bir faktör olarak, santral venin kas sistemi eksantrik ve longitudinal dallardan oluşur. Dallandığı zaman türbülans olmakta ve lokal staz gelişmektedir (2). Bu iki faktör primer venöz trombotik olaya yol açmakta, lokal arteriyel kan basıncını artırmaktadır. Bu durum tromboz sonrası kanamaya yol açmaktadır (3).

Literatürde adrenal infarkt ve hemoraji ile ilgili olarak bir tartışma söz konusudur. Hemorajiye infarkt mı neden oluyor yoksa infarkt hemorajiden mi kaynaklanıyor net anlaşılamamıştır. 1976 'da yapılan bir çalışmada, venöz trombozun bezde oluşmuş önceki hemorajiden olması muhtemel olduğu belirtilmiş ve bu durumun mikrovasküler seviyede ya da ana adrenal vende olabileceğinden bahsedilmiştir (4).

AFA pozitifliği olması durumunda her iki adrenal bezin etkilenmesi ile ilgili olarak bazı mekanizmalar öne sürülmüştür. Hücrelerdeki endosom ve lizozomların hücrelerde kolesterol transportuna ve protein sınıflandırmasına katkı sağlayan önemli organeller olduğu gösterilmiştir. Bu organellerin membranlarının, kolesterol depolanmasında ve transportunda önemli role sahip lizobifosfatidik asid (LBPA) içeriğinin yüksek olduğu gösterilmiştir (5). AFA için LBPA'nın hedef olduğu gösterilmiştir. LBPA'ya karşı gelişen antikorlar hücrelerde kolesterol birikimine neden olur. Endotel hücrelerinde aynı mekanizma katepsin $D$ gibi lizozomal proteinazların sekresyonuna neden olan C1-M6PR (Cation-Dependent Mannose 6-Phosphate Receptor) gibi düzenleyici proteinlerin yeniden dağılımına yol açar (6). Proteinazlar lokal olarak endotel hücrelerini aktive edebilir ve prokoagulan bir duruma yol açabilir (7). Anatomik olarak zona fascicularis adrenal korteksin $\% 75$ 'ini oluşturur ve hücreleri kolesterolden zengindir. Yüksek miktarda endosom ve LBPA içerirler. Böylece AFA özellikle bu lokalizasyonu tutar. AFA lokal olarak yükselir ve yukarıda bahsedilen mekanizmalarla hemostatik mekanizmaları etkiler ve lokal mikrotromboz ve postinfarkt hemorajiye yol açar.

AFA sendromu, SLE hastalarının \%30'unda görülebilir (8). Hastamızda da tekrarlayan venöz trombotik komplikasyonlarla birlikte SLE'ye sekonder AFA sendromu düşünüldü. AFA sendromunda protrombotik olayları açıklamak için birçok mekanizma öne sürülmüştür. Bu durumun AFA'nın protrombin, anneksin $\mathrm{V}$, plazmin ve endotel hücrelerindeki adezyon moleküllerinin aktivasyonu ile etkileşimi nedeniyle olması olasıdır (9). Kanama, AFA sendromunun nadir bir komplikasyonudur. Büyük prospektif çalışmalarda, bilateral adrenal hemoraji-adrenal infarktın, AFA sendromu olan hastaların \%1'inden azında görüldüğü 
gösterilmiştir (10). Primer adrenal yetmezlik, antifosfolipid sendromunda nadir görülür, katastrofik APS hastalarının \%13'ünde bildirilmiştir, ölümcül seyredebilir. Vakamızda, erken tanı konularak steroid replasmanına başlandığı için bu durum mortal seyretmemiştir. Adrenal hemoraji görünümü tamamen regrese olduğu halde adrenal yetmezlik hastamızda devam etmektedir.

AFA sendromunda görülen adrenal yetmezliğin patogenetik mekanizması tam olarak bilinmemekle birlikte; bu hastalardaki artmış koagülasyon durumu sorumlu tutulmaktadır. Adrenal yetmezliğin, ana adrenal ven ya da mikrovasküler düzeyde oluşan venöz tromboz sonrası hemorajiye bağlı olduğu düşünülmektedir. AFA sendromlarında daha sık görülen pulmoner emboli ve derin ven trombozunun yanı sıra adrenal venlerde de trombotik sürecin olabileceği akılda tutulmalıdır. Tromboz geçirmemiş (asemptomatik) AFA pozitif (özellikle lgG-AKA veya $L A$ ) hastalarda öncelikle tromboza yatkınlık yaratan diğer risk faktörlerinin (sigara, östrojen kullanımı, hipertansiyon, hiperlipidemi, diyabet gibi) ortadan kaldırılması veya azaltılması gereklidir. Uzun süreli aktivitesiz kalmaktan kaçınılmalıdır. AFA ilişkili adrenal yetmezlik genellikle kalıcı olup, nadiren düzelebilmektir. $\mathrm{Bu}$ nedenle bu hastaların uzun dönem takibi gerekmektedir. Bilateral adrenal hemorajiyle gelen hastalarda AFA varlığı araştırılmalıdır.

\section{Kaynaklar}

1. Berneis K, Buitrago-Téllez C, Muller B, Keller U, Tsakiris D. Case Report. Antiphospholipid syndrome and endocrine damage: Why bilateral adrenal thrombosis? Eur J Haematol 2003;71(4):299-302.

2. Presotto F, Fornasini F, Betterle C, Federspil G, Rossato M. Acute adrenal failure as the heralding symptom of primary antiphospholipid syndrome: Report of a case and review of the literature. Eur J Endocrinol 2005;153(4):507-14.

3. Espinosa G, Santos E, Cervera R, et al. Adrenal Involvement in the Antiphospholipid Syndrome: Clinical and immunologic characteristics of 86 patients. Medicine 2003;82(2):106-18.

4. Fox B. Venous infarction of the adrenal glands. J Path 1976;119(2):65-89.

5. Kobayashi T, Beuchat $\mathrm{MH}$, Lindsay $\mathrm{M}$, et al. Late endosomal membranes rich in lysobisphosphatidic acid regulate cholesterol transport. Nat Cell Biol 1999;1(2):113-8.

6. Galve-de Rochemonteix B, Kobayashi T, Rosnoblet C, et al. Interaction of anti-phospholipid antibodies with late endosomes of human endothelial cells. Arterioscler Thromb Vasc Biol 2000;20(2):563-74

7. Dunoyer-Geindre S, Kruithof EK, Galve-de Rochemonteix B, et al. Localization of beta 2-glycoprotein 1 in late endosomes of human endothelial cells. Thromb Haemost 2001;85(5):903-7.

8. Camerun JS. Lupus nephritis. J Am Soc Nephrol 1999;10(2):413-24.

9. Esmon NL, Smirnov MD, Esmon CT. Lupus anticoagulants and thrombosis: The role of phospholipids. Haematologica 1997;82(4):474-7.

10. Boonen E, Vervenne H, Meersseman P. Reduced cortisol metabolism during critical illness. N Engl J Med. 2013;368(16):147788. 